\title{
Kinetic Studies on State of the Art Solid Oxide Cells
}

Njodzefon, Jean-Claude; Graves, Christopher R.; Hjelm, Johan; Mogensen, Mogens Bjerg; Weber, André

Published in:

Electrochemical Society. Meeting Abstracts (Online)

Publication date:

2014

Document Version

Publisher's PDF, also known as Version of record

Link back to DTU Orbit

Citation (APA):

Njodzefon, J-C., Graves, C. R., Hjelm, J., Mogensen, M. B., \& Weber, A. (2014). Kinetic Studies on State of the Art Solid Oxide Cells. Electrochemical Society. Meeting Abstracts (Online), MA2014-02, [2040].

\section{General rights}

Copyright and moral rights for the publications made accessible in the public portal are retained by the authors and/or other copyright owners and it is a condition of accessing publications that users recognise and abide by the legal requirements associated with these rights.

- Users may download and print one copy of any publication from the public portal for the purpose of private study or research.

- You may not further distribute the material or use it for any profit-making activity or commercial gain

- You may freely distribute the URL identifying the publication in the public portal

If you believe that this document breaches copyright please contact us providing details, and we will remove access to the work immediately and investigate your claim 


\section{Kinetic Studies on State of the Art Solid Oxide Cells}

Tuesday, 7 October 2014: 17:00

Sunrise, 2nd Floor, Galactic Ballroom 4 (Moon Palace Resort)

J. C. Njodzefon, C. Graves, J. Hjelm (Department of Energy Conversion and Storage, Technical University of Denmark), M. B. Mogensen (Technical University of Denmark), and A. Weber (Karlsruhe Institute of Technology)

\section{Introduction}

The Solid Oxide Fuel Cell (SOFC), which converts hydrogen as well as hydrocarbon fuels directly into electricity, has demonstrated almost comparable performance when operated reversely as Solid Oxide Electrolyser Cell (SOEC) for electrical energy storage as fuels. In both applications of the technology, cell optimization and eventual commercialisation requires a sound understanding of the mechanisms that affect performance and stability. These mechanisms depend on operation conditions like temperature, gas composition, fuel utilisation and current load as well as on gradients along cell and stackand cell microstructure. This increases the complexity of the systems, such that deconvolution and analytical description of the involved mechanisms becomes a major challenge, especially if both macroscopic trends as well as fundamental chemistry are to be accommodated. The electrode reaction kinetics is one such mechanism.

\section{Experimental}

The investigated single cells with a $4 \times 4 \mathrm{~cm}^{2}$ active electrode area are anode supported cells with Ni/3YSZ substrates (ca. $0.3 \mathrm{~mm}$ ), Ni/8YSZ anodes (ca. $10 \mu \mathrm{m}$ ), 8YSZ electrolytes (ca. $10 \mu \mathrm{m}$ ), $\mathrm{Ce}_{0.9} \mathrm{Gd}_{0.1} \mathrm{O}_{2-\delta}$ buffer layers (ca. $1 \mu \mathrm{m}$ ) and $\mathrm{La}_{0.6} \mathrm{Sr}_{0.4} \mathrm{CoO}_{3-\delta} / \mathrm{Ce}_{0.9} \mathrm{Gd}_{0.1} \mathrm{O}_{2-\delta}$ cathodes (ca. $30 \mu \mathrm{m})$.

The cells were characterised through electrochemical impedance spectroscopy at open circuit voltage and under current load. Current/voltage characteristics were recorded at different temperatures and gas compositions. The fuel utilization and current density range were chosen to emulate practical conditions.

Figure 1 displays the Distribution of Relaxation Times (DRT) ${ }^{1}$ of spectra recorded at varying current densities in SOFC mode at 700 - and at $800^{\circ} \mathrm{C}$ ensuring a maximum fuel utilization of $60 \%$ in three different fuel electrode gas mixtures. Considering that the area beneath a peak represents the Area Specific Resistance (ASR) of the given dynamic process, it is clear that depending on operation temperature and fuel composition the processes make varying contributions to the overall cell resistance.

\section{Current vs. Overpotential Relation}

The ASRs of the processes were obtained through Complex Non-linear Least Squares fit of the spectra with an equivalent circuit model $^{2}$. The DRT was used for pre-identification of initial fit parameters. 
By integration of the ASRs vs current density, the corresponding overpotential curves were obtained, as displayed in Figure 2 for the electrochemical oxidation of $\mathrm{H}_{2}$ at the Ni/YSZ electrode. (f $>10^{3} \mathrm{~Hz}$ in Figure 1 )

Figure 2 reveals that the overpotential associated with the electrochemical oxidation of $\mathrm{H}_{2}{ }^{2}$ (and CO) at the Ni/YSZ electrode at all current densities increases from $\mathrm{H}_{2} / \mathrm{H}_{2} \mathrm{O}$ to $\mathrm{H}_{2} / \mathrm{CO}_{2}$ and $\mathrm{CH}_{4} / \mathrm{H}_{2} / \mathrm{H}_{2} \mathrm{O}$ fuel compositions. This is probably because in the reformate cases, $\mathrm{H}_{2}$ has to be replenished through the water gas shift reaction ${ }^{2}$ and also at equilibrium the $\mathrm{H}_{2} / \mathrm{H}_{2} \mathrm{O}$ case contains more $\mathrm{H}_{2} \mathrm{O}$. The cooling effect of the endothermic steam reforming may contribute to a higher overpotential in $\mathrm{CH}_{4} / \mathrm{H}_{2} / \mathrm{H}_{2} \mathrm{O}$ mixture. Relative to the overall potential drop in the investigated current density range, it can be claimed though that under these conditions and within the limits of accuracy, the Ni/YSZ electrode displays comparable performance in the three different fuel gas compositions.

\section{Outlook}

In this work experimental results of investigations on cells with varying microstructure of the fuel electrode operated in $\mathrm{H}_{2} / \mathrm{H}_{2} \mathrm{O}$ and reformate mixtures will be presented. Detailed impedance analysis will be used to determine the current/overpotential relationships and corresponding partial pressure dependencies. This will provide a solid basis for discussion of the highly debated analytical description of the electrochemical reaction overpotential of the Ni/YSZ electrodes.

\section{References}

1. H. Schichlein A.C. Müller, M. Voigts, A. Krügel, and E. Ivers-Tiffée, J. Appl. Electrochem., 32, 875 (2002). 
2. A. Kromp, A. Leonide, A. Weber, E. Ivers-Tiffée, J. Electrochem. Soc., 158 (8), B980-B986 (2011).
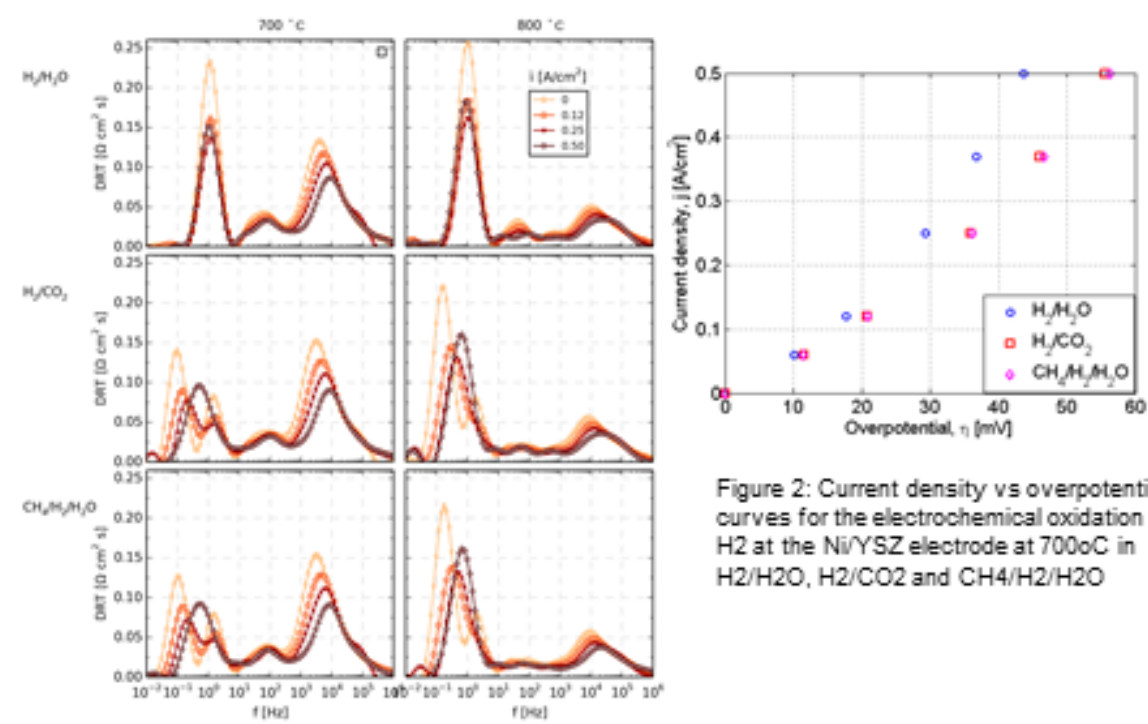

Figure 2: Current density vs overpotential curves for the electrochemical oxidation of $\mathrm{H} 2$ at the NiYSZ electrode at $7000 \mathrm{C}$ in $\mathrm{H} 2 / \mathrm{H}_{2} \mathrm{O}, \mathrm{H} 2 / \mathrm{CO}_{2}$ and $\mathrm{CH} 4 / \mathrm{H}_{2} / \mathrm{H}_{2} \mathrm{O}$

Figure 1: DRTs of impedance spectra at 700 - and $800{ }^{\circ} \mathrm{C}$ in SOFC mode from $0-0.5 \mathrm{~A} / \mathrm{cm}^{2}$ in $\mathrm{H}_{2} / \mathrm{H}_{2} \mathrm{O}, \mathrm{H}_{2} / \mathrm{CO}_{2}$ and $\mathrm{CH}_{4} / \mathrm{H}_{2} / \mathrm{H}_{2} \mathrm{O}(0.8 / 0.2-, 0.81 / 0.19$ - and $0.3 / 0.1 / 0.6$ atm respectively) and $0-60 \%$ fuel utilzation 